\title{
Decreasing Forage Allowance Can Force Cattle to Graze Broom Snakeweed (Gutierrezia sarothrae) as a Potential Biological Control
}

\author{
Michael H. Ralphs, ${ }^{1}$ Randy D. Wiedmeier, ${ }^{2}$ and Jeffrey E. Banks ${ }^{3}$ \\ Authors are ${ }^{1}$ Rangeland Scientist, USDA ARS Poisonous Plant Lab, Logan, UT 84341; ${ }^{2}$ Associate Professor, Animal Dairy and Veterinary Science \\ Department, Utah State University, Logan, UT 84322; and ${ }^{3}$ Juab County Agent, Utah State University Extension, Nephi, UT 84648.
}

\begin{abstract}
Broom snakeweed (Gutierrezia sarothrae [Pursh] Britt. \& Rusby) increases and dominates rangelands following disturbances such as overgrazing, fire, and drought. However, if cattle can be forced to graze snakeweed, they can be used as a biological tool to control it. Grazing trials were conducted in May and August 2004, 2005, and 2006 on a crested wheatgrass (Agropyron cristatum L.) seeding that had been invaded by broom snakeweed. Narrow grazing lanes were fenced with temporary electric fence and the cows were moved to a new lane each day. Forage allowance was limited to $24 \%-75 \%$ of the intake requirement. There were significant negative correlations $(P<0.05)$ between forage allowance and snakeweed utilization, suggesting it was the main factor driving snakeweed consumption. In the 2004 experiment, 7 cows in low body condition (4.6 body condition score, $\mathrm{BCS}$ ) and 7 cows in high body condition $(6.8 \mathrm{BCS})$ were grazed in separate lanes. The low body condition group grazed more snakeweed in the evening grazing period ( $26 \%$ of bites) than the high body condition group $(20 \%$ of bites, $P=0.03)$. In the 2005 experiment, one group (6 cows) received a protein/energy supplement high in bypass amino acids required for detoxification of terpenes; the second group received no supplement. There was no difference in snakeweed consumption between the supplement groups $(P=0.63)$. The major difference in diets in both years occurred in grazing periods during the day. Cows grazed perennial bunchgrasses first, then turned to cheatgrass (Bromus tectorum L.), and grazed snakeweed only when all other forage was depleted ( $20 \%$ of bites in the evening grazing periods). Cattle grazed $62 \%-95 \%$ of snakeweed plants and utilized $50 \%-85 \%$ of snakeweed biomass. Cattle can be forced to graze snakeweed by confining them to small areas and limiting alternative forage. Grazing reduced the snakeweed population.
\end{abstract}

\section{Resumen}

El "Broom snakeweed" (Gutierrezia sarothrae) aumenta y domina los pastizales después de un disturbio, como sobrepastoreo, fuego, y sequía. Sin embargo, si el ganado es forzado a apacentar el "Snakeweed" puede ser utilizado como una herramienta de control biológico para controlarlo. En mayo y agosto del 2004, 2005, y 2006 se condujeron experimentos de apacentamiento en praderas sembradas de "Crested wheatgrass" (Agropyron cristatum L.) que habían sido invadidas por "Broom snakeweed." En la pradera se establecieron franjas estrechas delimitadas por cercos eléctricos temporales en las que las vacas apacentaron y se movieron diariamente a una nueva franja. La asignación de forraje se limitó a $24 \%-75 \%$ de los requerimientos del animal. Hubo correlaciones negativas significativas $(P<0.05)$ entre la asignación de forraje y la utilización del "Snakeweed," sugiriendo que fue el factor principal que propició el consumo de "Snakeweed." En el experimento de 2004,7 vacas de condición corporal baja (clasificación de 4.6 de condición corporal, BCS) y 7 vaxcas de condición corporal alta (6.8 BCS) apacentaron en franjas separadas. El grupo de condición corporal baja consumió más "Snakeweed" en el periodo de apacentamiento vespertino ( $26 \%$ de bocados) que el de condición corporal alta ( $20 \%$ de bocados, $P=0.03)$. En el experimento del 2005, un grupo (6 vacas) recibió un suplemento proteico/energético alto en aminoácidos de sobrepaso requeridos para la desintoxicación de terpenos, mientras que un segundo grupo no recibió suplemento. No hubo diferencia $(P=0.63)$ entre grupos en el consumo de "Snakeweed." La principal diferencia en las dietas de ambos años ocurrió en los periodos de apacentamiento durante el día. Las vacas apacentaron el zacate amacollado primero, después siguieron con el "Cheatgrass" (Bromus tectorum L.) y solo apacentaron "Snakeweed" cuando todos los otros forrajes se terminaron (20\% de los bocados en los periodos de apacentamiento de la tarde). El ganado apacentó 62\%-95\% de las plantas de "Snakeweed" y utilizó 50\%-85\% de la de la biomasa del mismo. El ganado puede ser forzado a apacentar el "Snakeweed” confinándolo en pequeñas áreas y limitando los forrajes alternativos.

Key Words: body condition, grazing pressure, nutrient supplement, poisonous plant

\section{INTRODUCTION}

Broom snakeweed (Gutierrezia sarothrae [Pursh] Britt. \& Rusby) is one of the most wide-spread range weeds in the

Correspondence: Michael Ralphs, USDA ARS Poisonous Plant Lab, 1150 E 1400 N, Logan, UT 84341. Email: mralphs@cc.usu.edu

Manuscript received 5 July 2006; manuscript accepted 27 May 2007. western United States. Although a native plant, it increases with disturbances such as overgrazing, fire, and drought (reviewed by McDaniel and Torrell 1987). Broom snakeweed is very competitive with desirable grasses and greatly suppresses forage production (Ueckert 1979; McDaniel et al. 1982). It is not palatable to most large ungulates and is toxic to livestock, causing abortions (Dollahite and Anthony 1957). 
Although overgrazing is a principal cause for the increase in broom snakeweed, prescriptive grazing might provide the means of controlling it. The goal of using livestock to control weeds is to manipulate patterns of defoliation to place the target plant at a competitive disadvantage relative to other plants in the community (Vallentine 1989). Implementing grazing management principles (such as kind of livestock, season of use, stocking rate, and duration) can increase the probability the target plant will be defoliated at the phenological stage, and frequency and intensity that is most detrimental, without undue harm to associated forages (Walker et al. 1994). Defoliation of snakeweed during its rapid early growth in spring, or during flowering in late summer, may be more detrimental to its vigor and survival than the damage caused by grazing associated grasses. Defoliation of grasses is less detrimental during early growth prior to culm elongation (Caldwell et al. 1981), or in late summer when they are dormant (Cook and Stoddart 1963).

Ralphs and Wiedmeier (2004) positively conditioned cattle to eat snakeweed, but the preference did not persist in the field when other forage was available. However, as available forage became limited and grazing pressure increased, cattle were forced to consume snakeweed and grazed up to $59 \%$ of the plants. The overall objective of the current grazing study was to increase grazing pressure by reducing pasture size, and subsequent availability of herbaceous forage (forage allowance), to force cattle to graze snakeweed. The main hypothesis running through all three grazing experiments was that cattle will select snakeweed only when other forage becomes limited. The influence of body condition (2004) and bypass protein supplementation (2005) was evaluated as to their effect on snakeweed consumption. In 2004, cows in low and high body condition were compared in their consumption of snakeweed. The hypothesis of this experiment was that cows in low body condition would graze more snakeweed. Supplementation was evaluated in 2005. One group of cows was supplemented with bypass protein high in amino acids involved with detoxification of terpenes, to determine if it would allow the cows to consume more snakeweed than the unsupplemented group. The hypothesis was that supplemented cows would graze more snakeweed than unsupplemented. The objective of the third experiment was to determine the forage allowance threshold to maintain high utilization of snakeweed, yet provide as much herbaceous forage as possible to meet the nutrient needs of the cattle. Each year, grazing trials were conducted in spring before culm elongation of the perennial bunch grasses, and in late summer when grass was dormant, to determine if quality of associated forage affected snakeweed consumption. Collectively, these experiments focused on quantifying the relationship of daily forage allowance on temporal and total utilization patterns of snakeweed by cattle as the basis for determining the biologic control potential of cattle for this weedy species.

\section{METHODS}

The study site was located $12 \mathrm{~km}$ west of Nephi, Utah (lat $39^{\circ} 43^{\prime} 44.702^{\prime \prime} \mathrm{N}$, long $\left.111^{\circ} 53^{\prime} 28.891^{\prime \prime} \mathrm{W}\right)$. The original plant community was a Wyoming big sagebrush (Artemisia tridentata var. wyomingensis [Beetle \& A. Young] Welsh)/Indian ricegrass (Stipa bymenoides R. \& S.) plant community. A wildfire burned the site in July 1998 and it was seeded the following winter to crested wheatgrass (Agropyron cristatum L.). Snakeweed reinvaded the site and its density averaged 2.1 plants $\cdot \mathrm{m}^{-2}$. A 6-ha area was fenced with electric fence. The south half was grazed in spring, 18-27 May 2004, 18 May-1 June 2005, and 5-25 May 2006; the north half was grazed in late summer, 17-31 August 2004, 26 July-20 August 2005, and 1-24 August 2006.

\section{Forage Allowance and Standing Crop}

The amount of herbaceous forage (grass and forbs) available to the cows was restricted by reducing the pasture size to force them to graze snakeweed. Forage allowance is a specific index or measure of grazing pressure and is defined as the amount of forage available divided by the animal demand at a specific time (Vallentine 1989). Forage allowance in this study is presented as a percentage and was calculated using the standing crop at a point in time, divided by the predicted daily intake of the cows $\times 100\left(10 \mathrm{~kg} \cdot \mathrm{cow}^{-1} \cdot \mathrm{day}^{-1}\right.$; NRC 2000). Grazing lanes were fenced each day and the size adjusted to provide the desired forage allowance. The lanes were $138 \mathrm{~m}$ long, running the length of the pasture, and the width ranged from 3 to $10 \mathrm{~m}$, depending on the standing crop and desired forage allowance. Forage allowance was adjusted to obtain snakeweed utilization greater than $65 \%$ at the end of the day. Moving cows to new grazing lanes each day provided replication over time, and individual cows were the experimental units to which treatments of the respective experiments were applied.

Standing crop was sampled at the beginning and end of the 2004 trials. In spring 2005 and 2006, standing crop was sampled weekly to account for the rapid growth that was occurring. The availability of herbaceous forage in each of the grazing lanes each day was extrapolated from the difference between weekly standing crop estimates. Crested wheatgrass was dormant in late summer; therefore standing crop was sampled only at the beginning and end of the late summer trials in 2005 and 2006. At each sampling, four transects were located at 50-m intervals throughout the pastures. Along each transect, five $1 \times 0.5-\mathrm{m}$ quadrats were systematically placed at 20 -m intervals to uniformly cover the grazing area (20 plots at each sampling). Forage classes (crested wheatgrass, native bunchgrasses, cheatgrass (Bromus tectorum L.), forbs, and snakeweed) were clipped at ground level, bagged separately, dried for 48 hours in a forced-air oven at $60^{\circ} \mathrm{C}$, and weighed. Forage allowance was calculated for each lane each day by dividing the herbaceous forage standing crop by the animal forage demand.

Forage samples from the beginning standing crop transects were composited by forage class and analyzed for crude protein $(\mathrm{CP})$ by means of total $\mathrm{N}$ (LECO model FP-528; LECO Corp, St Joseph, MI), neutral detergent fiber (NDF) (ANKOM200 fiber analyzer; ANKOM, Fairport, NY) and in vitro dry matter digestibility (ANKOM Daisy II system). A crude resin fraction was extracted from the snakeweed samples. Whole plant samples from the standing crop transects were composited and a 0.5 -g subsample was extracted with $10 \mathrm{ml}$ methylene chloride for 1 hour, then filtered into an Erlenmeyer flask. The solvent was removed by evaporation on 
Table 1. Cow weights $(\mathrm{kg} \pm[\mathrm{SE}])$, average daily gains (ADG), and body condition scores (BCS) at the beginning and end of the spring and late summer grazing trials.

\begin{tabular}{|c|c|c|c|c|c|c|c|}
\hline \multirow[b]{2}{*}{ Year } & \multirow[b]{2}{*}{ Season } & \multirow[b]{2}{*}{ Group } & \multicolumn{3}{|c|}{ Weight } & \multicolumn{2}{|c|}{$\mathrm{BCS}^{2}$} \\
\hline & & & Begin & End & $\mathrm{ADG}^{1}$ & Begin & End \\
\hline & & & - & 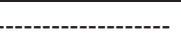 & $\mathrm{kg} / \mathrm{d}$ & & \\
\hline \multirow[t]{4}{*}{2004} & Spring & High BCS & $565(9)$ & $552(9)$ & $-0.53 \mathrm{a}$ & 6.8 & 7.0 \\
\hline & & Low BCS & 447 (14) & 435 (12) & $-0.53 \mathrm{a}$ & 4.6 & 4.4 \\
\hline & Late summer & High BCS & $504(14)$ & 469 (12) & $-1.40 b$ & 5.6 & 5.2 \\
\hline & & Low BCS & $359(12)$ & $360(14)$ & $0.06 \mathrm{a}$ & 3.4 & 3.4 \\
\hline \multirow[t]{4}{*}{2005} & Spring & Supplement & $507(20)$ & 545 (17) & $1.53 \mathrm{a}$ & 5.7 & -3 \\
\hline & & No Supp & $525(19)$ & $546(14)$ & $0.85 b$ & 5.8 & $-{ }^{3}$ \\
\hline & Late summer & Supplement & $569(13)$ & $582(16)$ & $0.29 \mathrm{a}$ & 6.5 & 6.3 \\
\hline & & No Supp & $569(12)$ & $553(12)$ & $-0.35 b$ & 6.5 & 6.3 \\
\hline \multirow[t]{2}{*}{2006} & Spring & & $536(14)$ & $558(15)$ & 0.85 & 5.4 & 5.0 \\
\hline & Late summer & & $589(14)$ & 595 (14) & 0.21 & 5.6 & 5.4 \\
\hline
\end{tabular}

${ }^{1}$ Average daily gains within seasons followed by different letters differ $(P<0.05)$.

${ }^{2}$ Standard errors for BSC ranged from 0.1 to 0.2 .

3 - data not collected.

a heating plate, and the extract was washed into tarred $8-\mathrm{ml}$ vials. The solvent was completely removed by placing the vials on a heating block with nitrogen flow, followed by a vacuum for 15 minutes, and then they were weighted and the crude resins were calculated as a percentage of dry matter.

Cows in each group grazed one lane each day and were moved to new lanes each morning. Diets were quantified by a bite count technique (Ortega et al. 1995). Each cow was observed for 5-minute periods during the morning, midday, and evening grazing periods. The number of bites of the following forage classes were counted: broom snakeweed, crested wheatgrass, native bunchgrasses, cheatgrass, forbs, and litter. The percentage of each class was calculated and used as an estimate of diet composition.

Snakeweed utilization was also measured. Each day, utilization of snakeweed plants in the previous lane was estimated in $221-\mathrm{m}^{2}$ quadrats placed at $5-\mathrm{m}$ intervals the length of each grazing lane. Within each quadrat, we counted the number of snakeweed plants, the number of plants grazed, and visually estimated the percentage utilization on each snakeweed plant ( $\%$ of biomass removed on each plant).

\section{Body Condition Experiment}

The hypothesis of this experiment was that cows in low body condition would consume more snakeweed than cows in high body condition. Fourteen 2-year-old, first-calf Angus heifers were used in 2004. Animals were handled by methods approved by an Institutional Animal Care and Use Committee \#1127. The heifers had been used the previous year in a positive conditioning study to condition them to graze snakeweed (Ralphs and Wiedmeier 2004). They were ranked according to the amount of snakeweed they consumed in the previous trial, along with their body weights. They were alternately placed into the two new groups to confound the previous treatments and equalize their propensity to graze snakeweed, as well as to equalize initial body weights of the groups. The respective groups were placed on diets in February that were calculated to bring them to a body condition score
(BCS) of 7 for the high group, and 3.5 for the low group. The BCS system used (Wagner et al. 1988) ranged from 1 being extremely emaciated, to 9 extremely obese, and 5 the ideal condition. The energy level of the diets differed, but all other nutrients were adequate (NRC 2000).

Cows were weighed before being taken to the field at the beginning of each trial, and at the end. Feed was removed in the afternoon and they were fasted overnight but had access to water, and they were weighed the next morning at 0730 hours. Body condition scores were given to each cow at these times by the same experienced technician. At the beginning of the spring grazing trial, the high condition group weighed $565 \mathrm{~kg}$ and had a BCS of 6.8 . The low condition group weighed $447 \mathrm{~kg}$ and had a BCS of 4.6 (Table 1). The heifers were scheduled to calve in June. At the beginning of the late summer trial and after they had calved, the high condition group weighed $504 \mathrm{~kg}$ and had a BCS of 5.6. The low condition group weighed $359 \mathrm{~kg}$ and had a BCS of 3.4. The calves were weaned before the late summer trial.

In the spring grazing trial, crested wheatgrass and the native bunchgrasses were in the vegetative stage of growth. Cheatgrass had set seed, but was still green. Crude protein requirement for the heifers in the spring while they were in the last trimester of gestation was 9\% (NRC 2000). Crude protein in the green grass was adequate for the cow's nitrogen requirement in the spring grazing trials. In the late summer trial, all herbaceous vegetation was dormant and snakeweed was in flower. Crude protein content of the dormant grasses was below the requirement for cows in the maintenance stage $(7 \% \mathrm{CP})$. In this late summer trial, we provided commercial protein blocks $(36 \%$ CP of which $25 \%$ CP equivalent was nonprotein $\mathrm{N}$ ) ad libitum, and consumption averaged $1 \mathrm{~kg} \cdot \mathrm{cow}^{-1} \cdot \mathrm{day}^{-1}$.

\section{Supplement Experiment}

The hypothesis of this experiment was that cows fed a supplement high in bypass amino acids involved with detoxification would enable them to consume more snakeweed 
than unsupplemented cows. A high proportion of sulfurcontaining and glucogenic amino acids in corn distillers grain are not degraded in the rumen, but are passed to the lower GI tract where they are absorbed intact. These amino acids are used in terpene detoxification (Freeland and Jansen 1974). If detoxification can be increased, cows might be able to consume more snakeweed without ill effects.

Twelve of the same cows ( 3 yr old, $564 \mathrm{~kg}$ ) were stratified by the amount of snakeweed they previously consumed, then were alternately placed in the supplemented or nonsupplemented group. Cows in the supplement group were individually fed the supplement each morning before the group was moved to a new pasture. The protein/energy supplement consisted of $19 \%$ soybean meal, $36 \%$ corn distillers grain, $42 \%$ ground corn, and $3 \%$ vitamin-mineral premix. It contained 2.09 Mcal $\mathrm{NEm} \cdot \mathrm{kg}^{-1}$ and $24.4 \%$ CP (dry matter basis), of which $12.7 \%$ was degradable intake protein (DIP) and $11.7 \%$ was undegradable intake protein (UIP). The supplement group received $0.54 \mathrm{~kg} \cdot$ day $^{-1}$ in the spring, which provided $23.46 \mathrm{~g}$ of essential amino acids escaping rumen degradation, of which $1.91 \mathrm{~g}$ was sulfur-containing and $20.35 \mathrm{~g}$ was glucogenic. In the late summer, the supplement group was fed $0.95 \mathrm{~kg} \cdot$ day $^{-1}$, which provided $41.01 \mathrm{~g}$ of essential amino acids escaping rumen degradation, of which $3.35 \mathrm{~g}$ was sulfur-containing and $35.58 \mathrm{~g}$ was glucogenic. The nonsupplemented group received only trace mineral salt blocks, which were available to both groups. The cows were scheduled to calve in September; thus the late summer period was during the critical last trimester of gestation.

\section{Forage Allowance Threshold}

In the two previous experiments, there appeared to be an upper forage allowance threshold, beyond which snakeweed bites and utilization declined dramatically. The objective of this experiment was to define the forage allowance threshold that maintains high snakeweed utilization, yet provides as much forage as possible to maintain condition of the cows.

The same 13 cows were used in this experiment as in the previous experiments, and they were scheduled to calve in September. Because the grasses were dormant in late summer, we supplemented all the cows with commercial protein blocks ( $36 \%$ CP, of which $25 \%$ was nonprotein N). They consumed an average of $1.4 \mathrm{~kg} \cdot \mathrm{cow} \cdot \mathrm{d}^{-1}$.

Forage allowance in the spring trial began at $33 \%$ and gradually increased. In the late summer trial, it began at $25 \%$ and gradually increased. We arbitrarily set snakeweed utilization at $65 \%$ as an acceptable level, and reduced forage allowance if utilization fell below that level. Grazing patterns were consistent in the previous experiments so we elected not to take bite counts in this experiment. Snakeweed utilization was measured as described above.

\section{Abortions}

Snakeweed causes abortions when grazed in the last trimester of gestation. The cows were bred so they would be grazing snakeweed during their most susceptible periods each year (May 2004, August 2005 and 2006) to evaluate the risk of abortions or toxicity under natural grazing conditions. We watched them closely for any signs of impending abortion or toxicity. In 2005, we ran serum blood chemistry before and after the late summer grazing trial to detect any signs of toxicity (sodium, potassium, chloride, $\mathrm{CO}_{2}$, anion gap, glucose, blood urea nitrogen, creatinine, calcium, magnesium, phosphorus, protein, albumin, cholesterol, bilirubin, alkaline phosphatase, lactate dehydrogenase, alanine transaminase serum glutamic oxaloacetic transaminase, alanine transaminase serum glutamate pyruvate transaminase). Analysis of variance (ANOVA) compared these serum chemistry values between treatment groups at the beginning and end of the grazing trial. Individual animals were experimental units.

\section{Statistical Analysis}

The overall objective over the 3 years of the study was to evaluate the influence of forage allowance on snakeweed consumption by cows and the degree of snakeweed utilization in the pastures. Correlations were run between forage allowance and snakeweed in diets, and snakeweed utilization in each of the 6 seasonal grazing trials. Treatment groups in the experiments in 2004 and 2005 were combined for the correlation analysis.

In 2004 and 2005, specific hypotheses were tested. Due to the changing forage allowance in each trial, we used forage allowance as a covariate in the ANOVA to quantify and isolate its effects in the statistical models. Bite counts of forage classes were converted to percent of bites. These percentage data were arc-sine square-root transformed before analysis to comply with the requirements of normality. The two experiments were analyzed separately. An initial adjustment period at the beginning of each seasonal trial was not included in the analysis. The diet data were analyzed in a repeated measures mixed model analysis of covariance. The fixed effects were treatment groups (BCS groups in 2004, supplement groups in 2005), season (spring and late summer trials), and period of the day (morning, midday, and evening). The random effects were animal within group, season by animal within group, and period by season by animal within group. Days of the trial, periods of the day, and seasons were the repeated measures. Individual cows were the experimental units. Average daily gains (ADG) were calculated, and along with body condition scores, compared between treatment groups in each season and year by ANOVA.

Snakeweed utilization and percent of snakeweed plants grazed were analyzed in a mixed model analysis of covariance, comparing groups and seasons as fixed effects, and random effects were plants nested within plots, lanes, and seasons. The percent utilization data were arc sine transformed before analysis to comply with normality and equal variances.

\section{RESULTS}

\section{Snakeweed Density, Standing Crop, and Nutrient Content of Forage}

Snakeweed density averaged $2.1 \pm 0.05$ plants $\cdot \mathrm{m}^{-2}$ in 2004, and declined to $1.12 \pm 0.03$ in 2005 and $0.90 \pm 0.6$ in 2006 . Annual precipitation for 2004 was $23 \%$ below average, which could have contributed to the decline in the snakeweed population in 2005 . However, the decline of snakeweed plants in grazed pastures was $50 \%$ greater than in the ungrazed areas, 
Table 2. Standing crop $\left(\mathrm{kg} \cdot \mathrm{ha}^{-1} \pm[\mathrm{SE}]\right)$ of forage classes at the beginning and end of the spring and late summer grazing trials.

\begin{tabular}{|c|c|c|c|c|c|c|c|c|}
\hline Year & Season & Time & Crested wheat & Native bunch & Cheat grass & Forb & Snake weed & Total \\
\hline & & & -".--.--- & 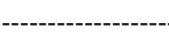 & - & 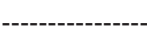 & & \\
\hline \multirow[t]{4}{*}{2004} & Spring & Begin & $110(11)$ & $19(4.6)$ & 63 (12.2) & $51(8.7)$ & $243(14)$ & $469(42)$ \\
\hline & & End & $29(5.8)$ & $7(3.5)$ & $21(6.0)$ & $21(4.8)$ & $40(10)$ & $118(14)$ \\
\hline & Late summer & Begin & $240(31)$ & $17(8.3)$ & $44(13.7)$ & $22(12.3)$ & 377 (78) & $700(77)$ \\
\hline & & End & $26(5.5)$ & -1 & -1 & $3(1.6)$ & $77(20)$ & $106(24)$ \\
\hline \multirow[t]{7}{*}{2005} & Spring & $5 / 4$ & 144 (18) & $42(11)$ & $81(28)$ & $65(15)$ & $220(47)$ & $552(71)$ \\
\hline & & $5 / 13$ & $168(21)$ & $67(24)$ & $73(26)$ & $67(16)$ & 353 (126) & $613(111)$ \\
\hline & & $5 / 19$ & $178(46)$ & $70(23)$ & $155(72)$ & $94(72)$ & $209(83)$ & $705(95)$ \\
\hline & & $6 / 1$ & $316(76)$ & $30(19)$ & $259(65)$ & $94(27)$ & $183(93)$ & 882 (155) \\
\hline & & End & $12(6)$ & $3(1)$ & $15(7)$ & $11(5)$ & $100(31)$ & $140(33)$ \\
\hline & Late summer & Begin & 609 (84) & $62(26)$ & $124(23)$ & $101(34)$ & $263(66)$ & $1159(100)$ \\
\hline & & End & $41(7)$ & $1(1)$ & $19(3)$ & $1(1)$ & 27 (9) & $88(12)$ \\
\hline \multirow[t]{6}{*}{2006} & Spring & $5 / 2$ & $134(23)$ & $50(22)$ & $11(11)$ & $144(26)$ & $103(28)$ & $443(49)$ \\
\hline & & $5 / 10$ & $197(20)$ & 67 (19) & $12(7)$ & $160(38)$ & $163(47)$ & $600(75)$ \\
\hline & & $5 / 16$ & 261 (32) & $50(2)$ & $96(33)$ & $143(37)$ & $132(38)$ & $683(72)$ \\
\hline & & End & $37(6)$ & -1 & -1 & 0 & $42(9)$ & $77(7)$ \\
\hline & Late summer & Begin & $495(63)$ & $61(19)$ & $112(18)$ & $10(5)$ & $134(44)$ & $813(72)$ \\
\hline & & End & $47(7)$ & -1 & -1 & $2(1)$ & $12(3)$ & $61(9)$ \\
\hline
\end{tabular}

${ }^{1}$ Total grasses at the end of the late summer trial were pooled into a single class.

suggesting that grazing did reduce snakeweed density after 1 year. Following above average precipitation in 2005, snakeweed density increased in the ungrazed areas but continued to decline in the grazing lanes (M. H. Ralphs, unpublished data, 2006). Change in snakeweed density and plant community response will be evaluated in subsequent years.

Standing crop of snakeweed declined in successive years (Table 2). Mean snakeweed standing crop at the beginning of spring and summer trials was similar to total herbaceous forage in $2004\left(310 \mathrm{~kg} \cdot \mathrm{ha}^{-1}\right.$ vs. $283 \mathrm{~kg} \cdot \mathrm{ha}^{-1}$, respectively), but snakeweed declined and herbaceous forage increased under this extremely heavy grazing regime. Precipitation in 2005 was $24 \%$ above average, resulting in higher standing crop of crested wheatgrass and cheatgrass than in other years. Standing crop of crested wheatgrass was more than double in late summer compared with spring, reflecting the accumulated summer's growth each year. Standing crop of all forage classes declined from beginning to end of each trial. Little herbaceous forage remained at the end of each trial, and snakeweed biomass was reduced $60 \%-90 \%$.

Crude protein content of crested wheatgrass in the spring $2004(13.6 \%)$ and $2005(14.3 \%$, Table 3$)$ exceeded the CP requirement for pregnant cows ( $9 \%$ CP; NRC 2000). However, $\mathrm{CP}$ content of grasses in the late summer 2004 (6.4\%) was below the requirement for dry cows $(7 \% \mathrm{CP})$, and less than half the requirement for pregnant, near-term cows in late summer 2005 (4.0\% CP). The low CP content of crested wheatgrass in summer 2005 was inversely proportional to its increased biomass from above average spring and summer precipitation. Crude protein content of snakeweed in spring was $11.4 \%$ and $10.2 \%$, respectively, for 2004 and 2005, and in late summer was $9.1 \%$ and $6.9 \%$, respectively, for 2004 and 2005. Fiber content of snakeweed was similar to grasses in spring, but was much lower than the grasses in late summer. Digestibility of snakeweed was much lower than other forages in both spring and late summer, probably because of the high crude resin concentration (Table 3). Crude resins ranged from $5.4 \%$ to $6.8 \%$ in spring and increased to $10.9 \%$ to $18.9 \%$ in late summer. Resins in snakeweed apparently accumulate over the growing season.

\section{Body Condition Trial}

There was a period-of-day main effect $(P<0.001)$ and groupby-period $(P=0.08)$ interaction of snakeweed in cattle diets. Cows consumed increasing amounts of snakeweed as the day progressed. When the periods were analyzed separately, the low body condition group consumed more snakeweed in the evening period than the high condition group $(P=0.03$, Fig. 1$)$. There was no difference between the body condition groups in the amount of snakeweed utilized in the pastures $(P=0.48)$ in the 2004 trial.

\section{Supplement Trial}

Supplement groups did not differ in snakeweed consumption $(P=0.63)$. There was a period effect $(P<0.001)$, in which the cows increased consumption of snakeweed over the day, similar to 2004.

There was a season-by-group interaction in utilization of snakeweed plants $(P=0.008)$. The supplement group utilized more snakeweed in the spring $(58 \%)$ than the nonsupplemented group $(46 \%, P=0.001)$, but there was no difference between groups in late summer $(85 \%$ vs. $87 \%$, respectively, $P=0.44)$. The overall utilization of snakeweed increased from $52 \%$ in spring to $86 \%$ in summer $(P=0.001)$.

We continued the supplement trial for an additional 10 days at the end of the late summer 2005 trial. Because utilization of snakeweed had been greater than $85 \%$ throughout the trial, we speculated that the pasture sizes might not have been large enough to provide enough snakeweed for treatment differences to be manifested. We increased pasture size to provide a forage 
Table 3. Nutrient concentration in species or forage classes and crude resins in snakeweed that was available to cattle in spring and late summer grazing trials. CP indicates crude protein; NDF, neutral detergent fiber; and IVTD, in vitro true digestibility.

\begin{tabular}{|c|c|c|c|c|c|c|c|}
\hline Nutrient & Season & Year & Crested & Native & Cheatgrass & Forb & Snakeweed \\
\hline & & & -----. & ---- & of dry weigh & ------ & ---------- \\
\hline \multirow[t]{4}{*}{$\mathrm{CP}$} & Spring & 2004 & 13.6 & 11.7 & 8.0 & 14.7 & 11.4 \\
\hline & & 2005 & 14.3 & 10.4 & 9.9 & 17.2 & 10.2 \\
\hline & Summer & 2004 & 6.4 & 6.5 & 6.2 & 12 & 9.1 \\
\hline & & 2005 & 4.0 & 4.5 & 4.1 & 8.0 & 6.9 \\
\hline \multirow[t]{4}{*}{ NDF } & Spring & 2004 & 52 & 55 & 59 & 43 & 50 \\
\hline & & 2005 & 47 & 61 & 60 & 39 & 57 \\
\hline & Summer & 2004 & 60 & 69 & 65 & 40 & 46 \\
\hline & & 2005 & 64 & 73 & 70 & 57 & 57 \\
\hline \multirow[t]{4}{*}{ IVTD } & Spring & 2004 & 85 & 75 & 72 & 74 & 60 \\
\hline & & 2005 & 82 & 72 & 63 & 72 & 52 \\
\hline & Summer & 2004 & 70 & 60 & 65 & 81 & 58 \\
\hline & & 2005 & 60 & 57 & 51 & 59 & 48 \\
\hline \multirow[t]{6}{*}{ Crude Resin } & Spring & 2004 & - & - & - & - & 6.6 \\
\hline & & 2005 & - & - & - & - & 5.4 \\
\hline & & 2006 & - & - & - & - & 6.8 \\
\hline & Summer & 2004 & - & - & - & - & 13.4 \\
\hline & & 2005 & - & - & - & - & 10.9 \\
\hline & & 2006 & - & - & - & - & 18.9 \\
\hline
\end{tabular}

allowance of $63 \%$. Snakeweed utilization dropped to about $50 \%$, leaving adequate snakeweed available from which the groups were able to select. Still, there were no differences between the supplement groups in snakeweed bites $(3 \%$, $P=0.38)$ or snakeweed utilization $(53 \%, P=0.44)$.

\section{Snakeweed Consumption as a Function of Limited Desirable Forage}

The major difference in diets occurred during periods of the day, which reflects the time in a lane and utilization of desirable forage. The amount of snakeweed consumed was strongly influenced by the availability of alternative forages. Cattle actively selected crested wheatgrass and native bunchgrasses when they entered new pastures each morning in both years (Fig. 2). These desirable bunchgrasses were generally depleted by midmorning, at which time the cows switched to cheatgrass. Most of the herbaceous forage was grazed by midday. When cattle resumed grazing in late afternoon and evening, they regrazed the short clumps of perennial bunchgrasses and searched for sprigs of cheatgrass (in spring) and litter (in late summer) from under the snakeweed plants. Cattle began taking some snakeweed as availability of herbaceous forage became limiting at midday, and maximized intake of snakeweed in the evening (24\% of bites in 2004 and $15 \%$ in 2005 ).

\section{Correlation with Forage Allowance}

The covariate, forage allowance, was not significant in the ANOVA of diets in the body condition trial in $2004(P=0.46)$, but it was significant in the supplement trial in $2005(P=0.001)$.
Correlations between forage allowance and bites of snakeweed were not significant in 3 of the 4 seasonal grazing trials (Figs. 3 and 4). We learned that forage allowance must be set very low at the beginning of the trials $(24 \%-33 \%)$ to quickly run out of herbaceous feed to force cattle to start grazing snakeweed. Once they started eating snakeweed, the cows apparently reached a threshold in the amount they could tolerate.

On the other hand, the covariate forage allowance was significant in the ANOVA of snakeweed utilization $(P<0.001)$ in all 4 trials in 2004 and 2005. There were also significant negative correlations between forage allowance and snakeweed utilization all 4 grazing trials (Figs. 3 and 4). Utilization of snakeweed was directly dependent on the amount of snakeweed in the grazing lanes which was determined by pasture size. Once forage allowance declined to the point of forcing cattle to graze snakeweed, they ate it up to an apparent level of tolerance. If there was more snakeweed available in the pasture than the cows could tolerate, utilization in that pasture declined. In the summer 2005 trial in which we systematically increased forage allowance, bite counts of snakeweed started to decline when forage allowance reached 50\%. When forage allowance reached $63 \%$, utilization of snakeweed declined dramatically (Fig. 4). Up to that point, utilization averaged $85 \%$ with $97 \%$ of the snakeweed plants grazed.

\section{Forage Allowance Threshold}

In spring 2006, as forage allowance increased, snakeweed utilization fell periodically. We reduced forage allowance then continued to increase it gradually. When forage allowance 
Snakeweed Consumption - 2004

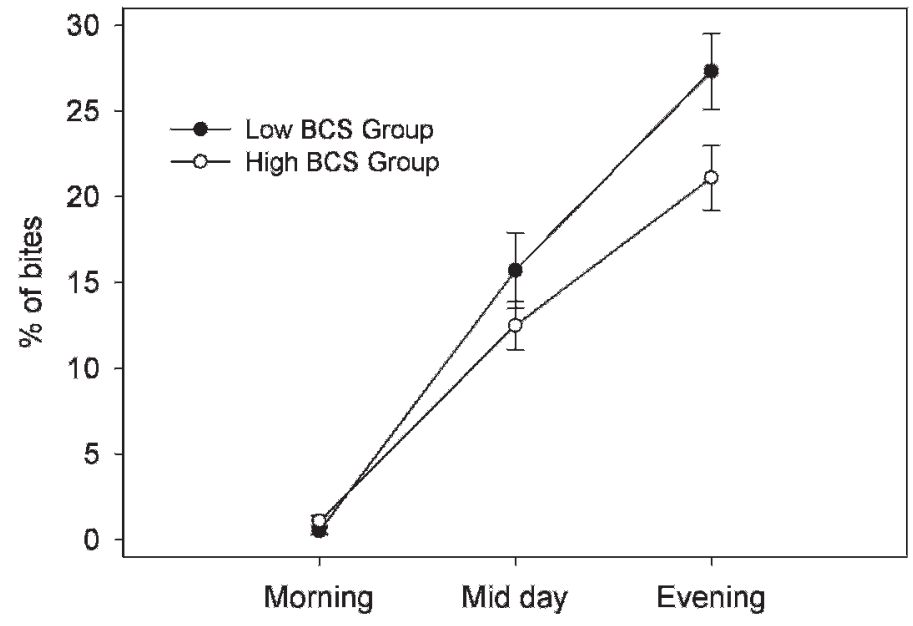

Figure 1. Snakeweed consumption (\% of bites) by cattle in low and high body condition groups during morning, midday, and evening grazing periods, averaged over season in the 2004 grazing trial. Error bars are standard errors. BCS indicates body condition score.

reached $57 \%$, snakeweed utilization dropped dramatically. We reduced forage allowance to $52 \%$ and utilization returned to $80 \%$. In the late summer trial, forage allowance started at $25 \%$ and gradually increased up to $75 \%$, at which snakeweed utilization fell (Fig. 5).

The forage allowance threshold apparently increased over the grazing trials each year. In spring 2004, the threshold to maintain a high level of snakeweed utilization was $33 \%$ and increased to $38 \%$ in the summer trial. In 2005 , the threshold in spring was $45 \%$ and $50 \%$ in summer. In 2006 , the threshold was $57 \%$ in spring and $75 \%$ in summer. This suggests a learned acceptance for snakeweed, but still not a preference for it when other feed is available.

\section{Abortions}

There were no signs of illness among the cows, or any indications of impending abortions. The blood chemistry

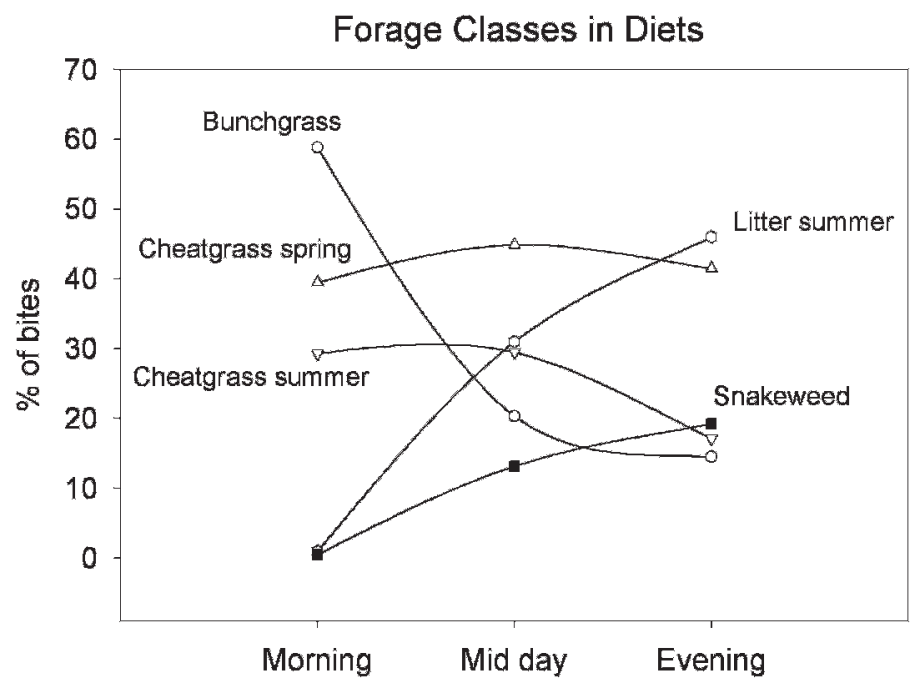

Figure 2. Forage classes in cattle diets (\% of bites) during the morning, midday, and evening grazing periods, averaged over both years.

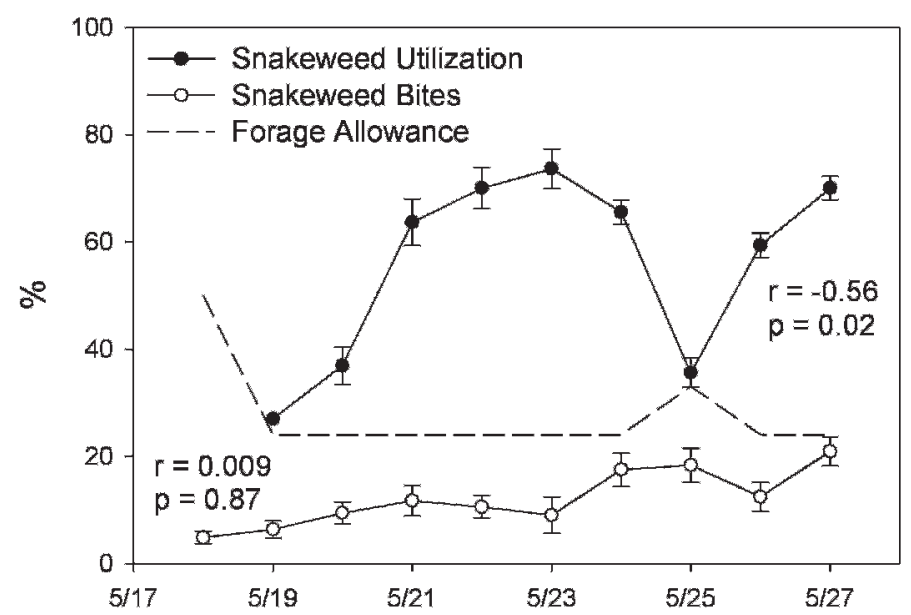

\section{Summer 2004}

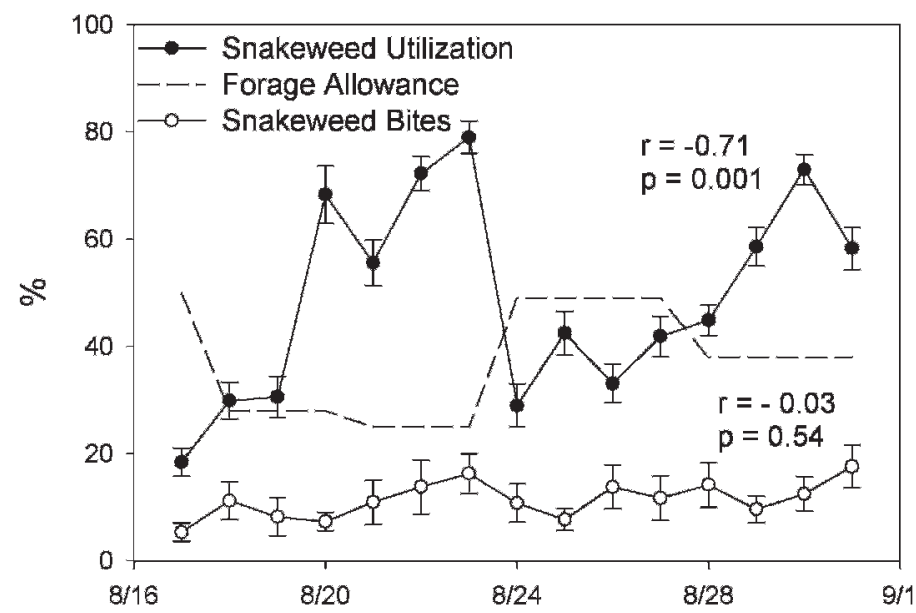

Figure 3. Snakeweed in cattle diets (\% of bites) in spring and summer body condition grazing trials in 2004, and resulting utilization of snakeweed ( $\%$ of snakeweed biomass removed). Forage allowance ( $\%$ of recommended intake) is shown and its correlation with snakeweed in diets and snakeweed utilization is presented. Error bars are standard errors.

values in 2005 revealed no liver or kidney damage, and there were no meaningful differences between the groups. A decrease in blood urea nitrogen $(13.8$ to $5.3, P<0.0001)$ from the beginning to end of the late summer 2005 trial, and an increase in creatinine ( 1.3 to $2.5, P<0.0001$ ), reflected a change from a high to low protein diet. However, there was no time-bygroup interaction $(P>0.32)$ suggesting the supplement group did not maintain protein status. However, the supplement group did gain more weight during this period than did the non supplemented group (Table 1).

\section{DISCUSSION}

\section{Chemistry}

Crude resins were very high in broom snakeweed, and doubled from the beginning of the spring grazing trials in early May to August each year. Terpenes and resins in other species of the 

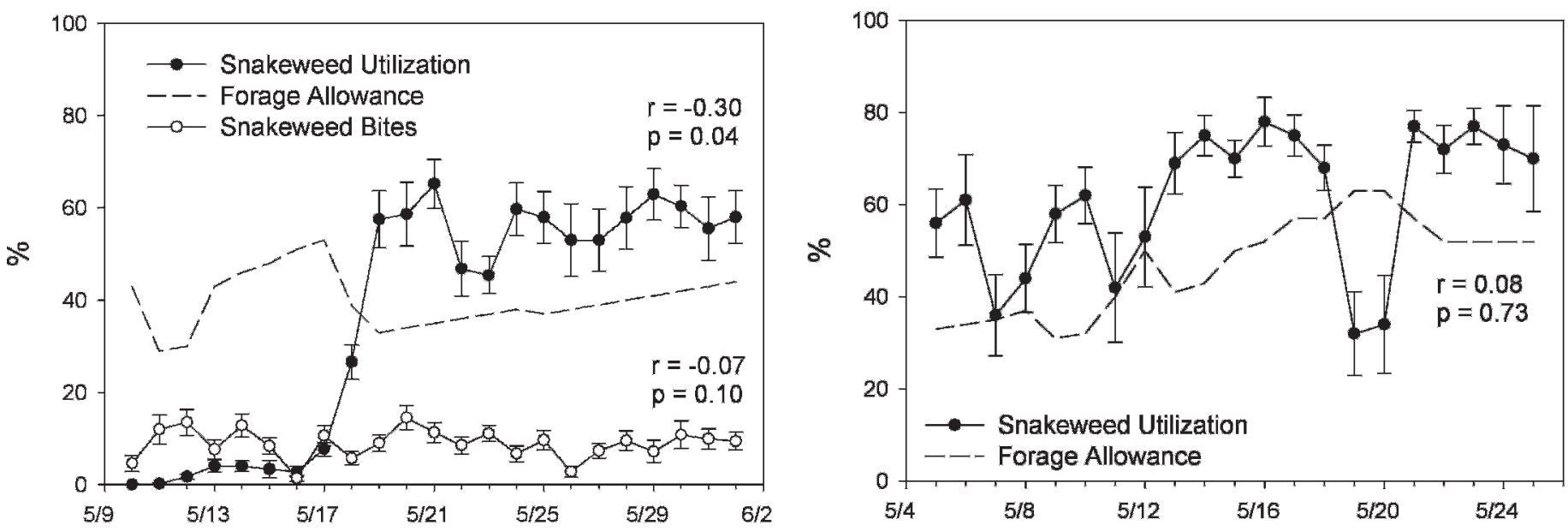

\section{Summer 2005}

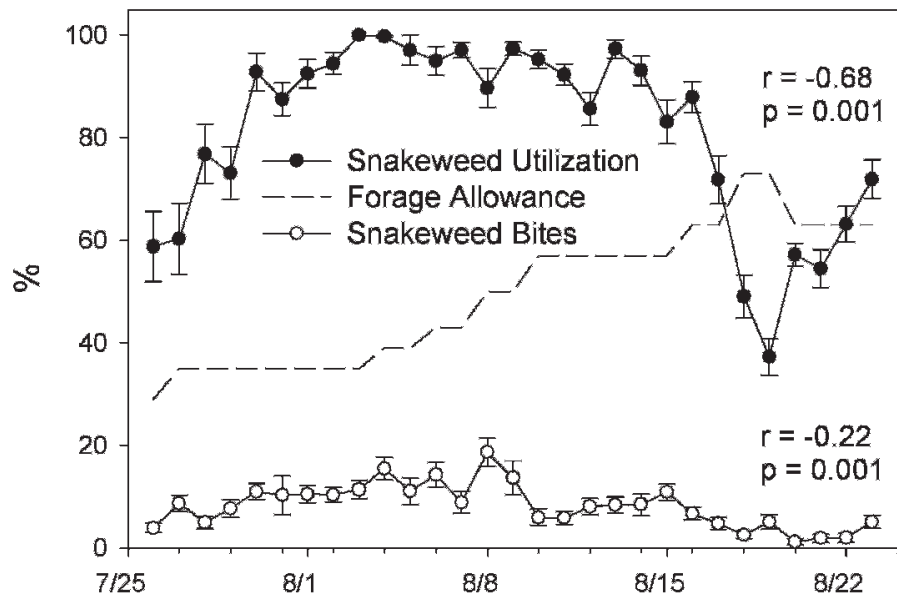

Figure 4. Snakeweed in cattle diets (\% of bites) in spring and summer supplement grazing trials in 2005, and resulting utilization of snakeweed ( $\%$ of snakeweed biomass removed). Forage allowance $(\%$ of recommended intake) is shown and its correlation with snakeweed in diets and snakeweed utilization is presented. Error bars are standard errors.

Compositae family, such as rubber rabbitbrush (Chrysothamnus nauseosus subsp. turbinatus; 36\%; Hegerhorst et al. 1988) and big sagebrush (Artemisia tridenta subsp. tridentata; $14 \%-$ 25\%; Kelsey et al. 1982; Cedarleaf et al. 1983) accumulate during the growing season and peak during flowering. We suspect the high level of resins in broom snakeweed contributed to its lack of palatability.

Cows reluctantly grazed snakeweed in this study. As they were turned into new pastures each morning, they consumed all of the herbaceous forage before selecting snakeweed. Snakeweed was as high in CP as grasses in the spring, and higher in the summer; and lower in NDF in both spring and summer. Yet, digestibility of snakeweed was much lower than grasses (Table 3). Mono- and diterpenes reduced digestibility and intake of mountain big sagebrush (Ngugi et al. 1995) and Ponderosa pine needles (Pfister et al. 1992). Recent research suggests individual monoterpenes were also responsible for reducing palatability of basin big sagebrush (Bray et al. 1991),

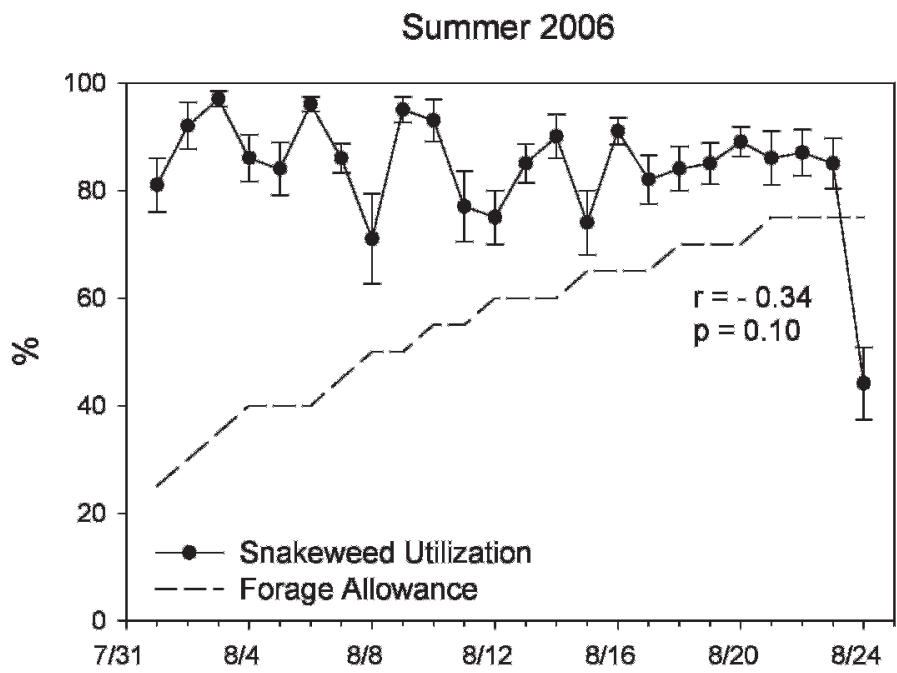

Figure 5 . Utilization of snakeweed (\% of snakeweed biomass removed) and forage allowance (\% of recommended intake) in spring and summer threshold grazing trials in 2006. Error bars are standard errors.

cessation of feeding (Dziba et al. 2006), and decreasing intake (Estel et al. 2002). We assume the relatively high levels of total resins act as feeding deterrents, either by directly reducing palatability, in suppressing rumen microbes, or by the direct physiological effect of suppressing feeding.

Snakeweed also contains toxic and abortifacient compounds. Dollahite et al. (1962) extracted a saponin fraction that caused abortions in rabbits, goats, and cattle at low doses, and caused death at high doses. Roitman et al. (1994) extracted several furano-diterpene acids and flavones from the resinous exudate in trichomes on leaves of snakeweed. These diterpene acids were structurally similar to isocupressic acid, the abortifacient compound in Ponderosa pine (Pinus ponderosa Laws) needles (Gardner et al. 1994). Gardner et al. (1999) speculated that some of the furano-diterpene acids in snakeweed could be abortifacient, and others could be toxic, and the relative concentrations determines whether animals are poisoned or abort. Our cows showed no signs of toxicity or abortion and the serum chemistry suggested no toxicity. 


\section{Body Condition}

Body condition had a slight effect on snakeweed intake under conditions of restricted forage allowance. Our cows in low body condition consumed more snakeweed in the evening grazing period than the group in high body condition in both spring and summer trials in 2004. Few studies have addressed the effects of body condition on ingestive behaviors. Theoretically, low body condition could increase intake of less palatable forages because cows graze less selectively and strive to replenish body energy reserves, or high body condition could facilitate intake of forages containing secondary compounds because more expendable energy would be available for detoxification. Lopez-Oritz (2002) reported thin cows in low body condition grazed greater amounts of lupine, and began eating lupine earlier than cows in higher body condition. Furthermore, sheep in low body condition absorbed more of the teratogenic alkaloid anagyrine and total alkaloids, and retained them longer than ewes in average body condition (Lopez-Ortiz et al. 2004), suggesting animals in low body condition might be more susceptible to poisoning. On the other hand, pregnant beef cows in high body condition tended to consume more ammoniated wheat straw than those in poor condition (Wiedmeier et al. 2002).

\section{Supplement}

The supplement in 2005 was designed to enhance the rumen bypass protein to provide precursor amino acids and additional energy needed to detoxify terpenes. However, the supplement in our study did not increase snakeweed consumption. In the late summer grazing trial, crude protein content of dormant grasses was very low $(4 \%)$, whereas the protein requirement for cows in their last trimester of gestation was high $(9 \% \mathrm{CP})$, reflecting the metabolic demand for protein in the developing fetus and the increased demand for both protein and energy for detoxification of secondary chemicals. The supplement was effective in sustaining weight gains in the supplement group $\left(0.29 \mathrm{~kg} \cdot \mathrm{day}^{-1}\right)$, as opposed to a loss of $0.35 \mathrm{~kg} \cdot \mathrm{day}^{-1}$ in the nonsupplemented group. The soybean meal component of the supplement was calculated to provided sufficient DIP for ruminal fermentation of the dry roughage, the ground corn provided supplemental energy, and the bypass UIP from distillers grain should have provided intact sulfur-containing and glucogenic amino acids required in detoxification.

Our results differ from the positive results of several studies showing supplements increased intake of chemically defended plants, such as sagebrush fed to sheep in pens and supplemented with barley (Banner et al. 2002), protein (Villalba et al. 2002), or increasing concentrations of both energy and protein (Villalba and Provenza 2005); sagebrush grazed by ewes in the field (Dziba et al. 2007); or goats supplemented with protein to increase juniper intake (Campbell et al. 2007). Smith et al. (1984), however, cautioned extrapolating between the detoxification ability between cattle and sheep, and among chemical substrates.

\section{Forage Allowance}

The change in grazing patterns from the time the cows entered a new lane in the morning, until they ceased grazing at night, illustrates the influence of grazing pressure on snakeweed consumption. Perennial bunchgrasses were preferred and sought out as the cows entered a new lane in the morning. As their availability declined, the cows switched to cheatgrass. As the herbaceous forage was depleted during midday, the cows licked up litter from under the shrubs. Snakeweed was the least palatable alternative, and cattle spent considerable time and effort licking up litter and sprigs of cheatgrass and regrazing short clumps of bunchgrasses between bites of snakeweed.

Other studies reported increased stock density, with accompanying increase in grazing pressure, increased utilization of less palatable shrubs such as shadscale (Atriplex confertifolia [Torr. \& Frem.] Wats) and black sage (Artemisia nova A. Nels.; Pieper et al. 1959), and big sagebrush and rabbitbrush (Chrysothammus nauseosus [Pallas] Britt.; Cook et al. 1962) on Utah's west desert. Heavy fall grazing by sheep reduced big sagebrush in Idaho (Laycock 1967). In the live oak savanna in west Texas, heifers heavily browsed mesquite, live oak (Quercus virginiana [Mill.]), sacahuista (Nolina texana S. Wats), and prickly pear (Opuntia macrorhiza Engelm) at the end of 21-day grazing periods in a high-intensity, low-frequency grazing system (Taylor et al. 1980); and in 3-day grazing periods of a short duration grazing system (Ralphs et al. 1990) when they ran out of other feed. On shortgrass prairies in Colorado, heifers grazing at heavy stocking rates eliminated broom snakeweed and other half shrubs (Hart and Ashby 1998).

In a study similar to ours in which lambs were moved to a new pasture each day, Shaw et al. (2006) reported lambs in the high density group (forage allowance of $21 \%$ from understory forage) consumed sagebrush for an average of $25 \%$ of the time over a 20 -day trial. Lambs in the low density group (91\% understory forage allowance) avoided grazing sagebrush. Lambs in a third group having the same stocking rate as the high density group, but 3 times the area for 3 days, depleted the understory the first day, then began eating sagebrush on the second and third day in a cyclic pattern. In subsequent preference trials, all groups under low stock density consumed very little sagebrush. Only when forage was limited were they forced to graze sagebrush.

The goal of biological control of weeds by grazing animals is to heavily graze the weed to the competitive advantage of the favored plants (Walker et al. 1994; Vallentine 1989). Plants cope with herbivory by either avoidance or tolerance (Briskie and Richards 1995). Most weed species rely on avoidance due to spines, other physical deterrents such as pubescence or tricombs, or aversive phytochemicals. If they are grazed, they might not have the tolerance mechanisms to replace lost photosynthetic material, and can be out-competed by grazing tolerant plants that rapidly replace photosynthetic material. Grasses, on the other hand, are generally tolerant of grazing. Grazing during vegetative growth prior to culm elongation (Caldwell et al. 1981; Olson and Richards 1988), and when the plant is dormant (Cook and Stoddart 1963), was least detrimental to crested wheatgrass. Our grazing periods were designed during these times to inflict the least amount of damage on crested wheatgrass and native perennial bunchgrasses, while heavily utilizing snakeweed during rapid growth in spring, or during flowering in late summer when carbohydrate demand is greatest.

Concentrating cattle in small grazing lanes with total defoliation of all forage can have adverse impacts on watershed values-soil compaction, reducing infiltration, and increasing runoff and erosion-if this practice continued. However, high- 
intensity thunderstorms did not occur during this study and we did not observe any erosion. We will measure the impact of grazing on the plant community in subsequent years.

\section{IMPLICATIONS}

Our cows were restricted to narrow grazing lanes and allocated herbaceous forage to provide only $24 \%$ to $75 \%$ of their daily intake requirement. They did not select snakeweed as long as other forage was available, but did increase consumption as availability of other forages declined during the day. Mean snakeweed consumption averaged $20 \%$ of bites during the evening grazing period. Cattle grazed $62 \%-95 \%$ of snakeweed plants and utilized $50 \%-85 \%$ of the snakeweed biomass.

Grazing pressure (low forage allowance) was the major factor forcing cattle to graze snakeweed. Modifying grazing behavior to enhance an animal's acceptance of target weeds has limited potential. Our positive conditioning trials to condition cattle to graze snakeweed increased intake in the pen, but the animals selected other species in the field when choices were available. The supplement trials referenced above increased intake of sagebrush and juniper in the pen when they were the sole choice, and in field grazing studies when other forage became limiting. We therefore conclude that behavior modification practices, such as conditioned preference, learned acceptance, supplements to detoxify secondary compounds, or body condition, might be used to increase an animal's consumption of weeds to a limited degree, but grazing pressure is the dominant factor forcing animals to select the target plant. Animals will always select plants that are relatively more palatable. Chemically defended weeds and shrubs are generally the least palatable plants in the community. Thus animals will exhaust other forages before they turn to these target plants.

However, grazing pressure can be manipulated. Grazing systems such as strip grazing and short duration grazing allows control of forage allowance. Forage allowance can be restricted in these grazing strategies so animals will rapidly consume the herbaceous forage and be forced to select the target plant. Rapid movement of animals to new pastures or lanes provides minimum nutrients to maintain animal condition.

The goal of this strategy is to force animals to graze weeds that generally have not evolved with grazing pressure, put them at a competitive disadvantage with grasses that are grazing tolerant, and reduce their presence in the plant community. We demonstrated that animal weights and body condition could be maintained, but gains might have to be sacrificed. Thus, the class of animal, its physiological condition, and time of year, would have to be selected when maintenance is acceptable. Furthermore, this high intensity grazing system requires additional labor to set up temporary electric fence and move animals frequently. In spite of the high labor input, this system could be feasible if herbicide or cultural control is not an option.

\section{LITERATURE CITED}

Banner, R. E., J. Rogosic, E. A. Burritt, and F. D. Provenza. 2000. Supplemental barley and charcoal increase intake of sagebrush by lambs. Journal of Range Management 53:415-420.
Bray, R. O., C. L. Wambolt, and R. G. Kelsey. 1991. Influence of sagebrush terpenoids on mule deer preference. Journal of Chemical Ecology 17:2053-2062.

BRISKE, D. D., AND J. H. RichaRds. 1995. Plant responses to defoliation: a physiological, morphological and demographic evaluation. In: D. J. Bedunah and R. E. Sosebee [EDS.]. Wildland plants: Physiological ecology and developmental morphology. Denver, CO: Society for Range Management. $p$. 672-679.

Caldwell, M. M., J. G. Richards, D. A. Johnson, R. S. Nowak, and R. S. Dzurec. 1981. Coping with herbivory: photosynthetic capacity and resource allocation in two semiarid Agropyron bunchgrasses. Oecologia 50:14-24.

Campbell, E. S., C. A. Taylor, J. W. Walker, C. J. Lupton, D. F. Waldron, and S. Landau. 2007. Effects of protein supplementation on juniper intake by goats. Rangeland Ecology and Management (in press).

Cedarlear, J. D., B. L. Welch, and J. D. Brotherson. 1983. Seasonal variation of monoterpenoids in big sagebrush (Artemesia tridentate). Journal of Range Management 36:492-494.

Cook, C. W., and L. A. Stoddart. 1963. The effect of intensity and season of use on the vigor of desert range plants. Journal of Range Management 16:315-317.

Cook, C. W., K. TAYLOR, and L. E. HarRIs. 1962. The effect of range condition and intensity of grazing upon daily intake and nutritive value of the diet on desert ranges. Journal of Range Management 15:1-6.

Dollahite, J. W., and W. V. Anthony. 1957. Poisoning of cattle with Gutierrezia microcephala, a perennial broomweed. Journal of American Veterinary Medical Association 130:525-530.

Dollahite, J. W., T. Shaver, and B. J. Camp. 1962. Injected saponins as abortifacients. Journal of American Veterinary Research 23:1261-1263.

Dziba, L. E., J. O. Hall, and F. D. Provenza. 2006. Feeding behavior of lambs in relation to kinetics of 1,8-cineole dosed intravenously or into the rumen. Journal of Chemical Ecology 32:391-408.

Dziba, L. E., F. D. Provenza, J. J. Villalba, and S. B. Atwood. 2007. Influence of terpenes and nutritional supplement on intake of sagebrush by sheep. Small Ruminant Research 69:203-207.

Estel, R. E., E. L. Fredickson, D. M. Anderson, K. M. Havstad, and M. D. Remmenga. 2002. Effects of four mono- and sesquiterpenes on the consumption of alfalfa pellets by sheep. Journal of Animal Science 80:3301-3306.

Freeland, W. J., and D. H. Janzen. 1974. Strategies in herbivory by mammals: the role of plant secondary compounds. The American Naturalist 108:269-289.

Gardner, D. R., L. F. James, K. E. Panter, J. A. Pfister, M. H. Ralphs, and B. L. Stegelmeier. 1999. Ponderosa pine and broom snakeweed: poisonous plants that affect livestock. Journal of Natural Toxins 8:27-34.

Gardner, D. R., R. J. Molyneux, L. F. James, K. E. Panter, and B. L. Stegelmeier. 1994. Ponderosa pine needle-induced abortion in beef cattle: identification of isocuprssic acid as the principal active compound. Journal of Agriculture and Food Chemistry 44:3257-3261.

HART, R. H., AND M. M. AshBy. 1998. Grazing intensities, vegetation and heifer gains: 55 years on shortgrass. Journal of Range Management 51:392-398.

Hegerhorst, D. F., R. B. Bhat, D. J. Weber, and E. D. McArthur. 1988. Seasonal changes of selected secondary plant products in Chrysothamnus nauseosus ssp. turbinatus. Great Basin Naturalist 48:1-8.

Kelsey, R. G., J. R. Stephens, and F. Shafizadeh. 1982. The chemical constituents of sagebrush foliage and their isolation. Journal of Range Management 35:617-622.

LAYcock, W. A. 1967. How heavy grazing and protection affect sagebrush-grass ranges. Journal of Range Management 20:206-213.

LOPEZ-ORITZ, S. 2002. Nutritional status, dietary preferences, and response to toxicosis of livestock exposed to lupine (Lupinus spp.) [dissertation]. Moscow, ID: University of Idaho. $110 \mathrm{p}$.

Lopez-Ortiz, S., K. E. Panter, J. A. Pfister, and K. L. Launchbaugh. 2004. The effect of body condition on disposition of alkaloids from silvery lupine (Lupinus argenteus Pursh) in sheep. Journal of Animal Science 82:2798-2805.

McDaniel, K. C., R. D. Pieper, and G. B. Donart. 1982. Grass response following thinning of broom snakeweed. Journal of Range Management 35:219-222.

McDaniel, K. C., and L. A. Torell. 1987. Ecology and management of broom snakeweed. In: J. L. Capinera [ED.]. Integrated pest management on rangeland, a hortgrass prairie perspective. Boulder, C0: Westview Press. p. 101-115. 
Ngugi, R. K., F. C. Hinds, And J. Powell. 1995. Mountain big sagebrush browse decreases dry matter intake, digestibility, and nutritive quality of sheep diets. Journal of Range Management 48:487-492.

NRC. 2000. National Research Council, Nutrient Requirements of Beef Cattle. Washington, DC: National Academic Press. 232 p.

OLSON, B. E., AND J. H. RICHARDS. 1988. Tussock regrowth after grazing: intercalary meristem and axillary bud activity of tillers of Agropyron desertorum. Oikos $51: 374-382$.

Ortega, I. M., F. C. Bryant, and D. L. Drawe. 1995. Contrasts of esophageal-fistula vs. bite-count techniques to determine cattle diets. Journal of Range Management 48:498-502.

Pfister, J. A., D. C. Adams, R. D. Wiedmeier, and R. G. Cates. 1992. Adverse effects of pine needles on aspects of digestive performance in cattle. Journal of Range Management 45:528-533.

Pieper, R., C. W. Cook, and L. E. Harris. 1959. Effect of intensity of grazing upon nutritive content of the diet. Journal of Animal Science 18:1031-1037.

Ralphs, M. H., M. M. Kothmann, and C. A. Taylor. 1990. Vegetation response to increased stocking rates in short-duration grazing. Journal of Range Management 43:104-108.

Ralphs, M. H., and R. D. Wiedmeier. 2004. Conditioning cattle to graze broom snakeweed (Gutierrezia sarothrae). Journal of Animal Science 82:3100-3106.

Roitman, J. N., L. F. James, and K. E. Panter. 1994. Constituents of broom snakeweed (Gutierrezia sarothrae), an abortifacient range plant. In: S. M. Colgate and P. R. Dorling [EDS.]. Plant-associated toxins, agricultural, phytochemical and ecological aspects. Wallingford, UK: CAB International. p. 345-350.

Shaw, R. A., J. J. Vallalba, and F. D. Provenza. 2006. Influence of stocking density and temporal patterns of forage allocation on diet mixing behavior of sheep grazing sagebrush steppe. Applied Animal Behavior Science 100:207-218.
Smith, G. S., J. B. Watkins, T. N. Thompson, K. Rozman, and C. D. Klaassen. 1984. Oxidative and conjugative metabolism of xenobiotics by livers of cattle sheep, swine and rats. Journal of Animal Science 58:386-395.

Taylor, C. A., M. M. Kothmann, L. B. Merrilll, and D. Elledge. 1980. Diet selection by cattle under high-intensity, low-frequency, short duration and Merrill grazing systems. Journal of Range Management 33:428-434.

UECKERT, D. N. 1979. Broom snakeweed: effect on shortgrass forage production and soil water depletion. Journal of Range Management 32:216-220.

Vallentine, J. F. 1989. Range development and improvements. New York, NY: Academic Press. p. 72-79.

Villalba, J. J., and F. D. Provenza. 2005. Foraging in chemically diverse environments: energy, protein and alternative foods influence ingestion of plant secondary metabolites by lambs. Journal of Chemical Ecology 31:123-138.

Villalba, J. J., F. D. Provenza, and R. E. Banner. 2002. Influence of macronutrients and activated charcoal on intake of sagebrush by sheep and goats. Journal of Animal Science 80:2099-2109.

Wagner, T. J., R. S. Lusby, J. W. Oltgen, J. Pakestraw, R. P. Wetteman, and L. E. Walters. 1988. Carcass composition in mature Hereford cows: estimation of effect on daily metabolizable energy requirement during winter. Journal of Animal Science 66:603-612.

Walker, J. W., S. L. Kronberg, S. L. A. Rowally, and N. E. West. 1994. Managing noxious weeds with livestock: studies on leafy spurge. In: Sheep research progress report no. 3. Dubois, ID: USDA/ARS Sheep Experiment Station. p. $125-135$.

Wiedmeier, R. D., K. C. Olson, B. A. Dent, and R. P. R. Schmidt. 2002. Utilization of low-quality forage as affected by beef cow body condition score. Proceedings Western Section of American Society of Animal Science 53:593-595. 